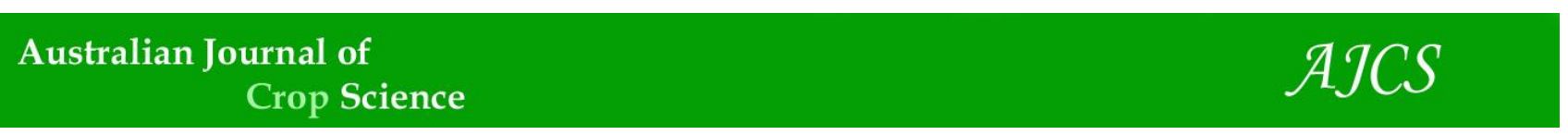

AJCS 14(01):204-211 (2020)

ISSN:1835-2707

doi: 10.21475/ajcs.20.14.01.p2334

\title{
Stochastic modeling of reference evapotranspiration in arid and semi-arid zones
}

\author{
Janilson Pinheiro de Assis ${ }^{1}$, Roberto Pequeno de Sousa ${ }^{1}$, Walter Rodrigues Martins ${ }^{2}$, Paulo César Ferreira \\ Linhares ${ }^{1}$, Eudes de Almeida Cardoso ${ }^{1}$ José Aluísio de Araújo Paula ${ }^{3}$, Mateus de Freitas Almeida dos \\ Santos $^{1}$, Isadora Lorrayne Basilio de Sousa ${ }^{1}$, Misael Bruno de Araújo ${ }^{1}$
}

\author{
${ }^{1}$ Federal Rural Semi-Arid University, Department of Agronomic and Forestry Sciences, Jitirana Research Group, \\ Mossoró-RN, 59625-900, Brazil \\ ${ }^{2}$ Center of Exact and Natural Sciences, Federal Rural Semi-Arid University, Mossoró-RN, 59625-900, Brazil \\ ${ }^{3}$ Consultant, Instructor and Doctor in Plant Science, Brazilian Service to Support at Micro and Small Enterprises of \\ Rio Grande do Norte (SEBRAE-RN), Mossoró, RN, Brazil
}

\section{*Corresponding author: janilson@ufersa.edu.br}

\begin{abstract}
The objective of this work was to estimate the probabilities of the reference evapotranspiration (mm), as well as its accumulated values during 10 days (decendial), in Mossoró, RN, Brazil. It wass done through the daily records of evapotranspirations obtained at the Meteorological Station of the Federal Rural University of Semi-Arid (UFERSA), in Mossoró, RN, using the Penman-Monteith method. No previous transformation of the data was necessary since the construction of the tables was based on the approximation of the variable to the Normal distribution. The odds were estimated by the Normal distribution for the confidence levels of $1 \%$ to $95 \%$ in the data period from 1970 to 2007, taking into account the results of the chi-square and KolmogorovSmirnov tests at $10 \%$ probability. From the adequacy of the process of construction of the tables, it can be conclude and that studied values have important subsidies for planning of agricultural activities in the region, where the maximum benefits of their benefits are taken, avoiding their harmful effects.
\end{abstract}

Keywords: climatology, modeling, probability distribution, adherence testing.

Introduction

The major global attention has been taken by changes in climatic conditions, contributing to global warming. Climatic changes may affect the water demand of the plants, since evapotranspiration is affected by changes in climatic parameters (Leonidas, 2011).

The potential evapotranspiration (Etp or Eto) is the amount of water transferred to the atmosphere by evaporation and transpiration. In a time unit, a vast surface can completely be covered with vegetation of low size and well-supplied water (Sentelhas and Angelocci, 2007). The main purpose would be to understand climatological water balances necessary for development and harvesting of crops, in the monitoring of droughts, and in the establishment of agricultural zoning (Biscaro, 2007). We also need to determine water losses in reservoirs, water amount, water balance in a river basin, to calculate soil water storage of irrigation and drainage projects to better design and manage the systems (Carvalho et al., 2011).

The probability of occurrence of estimated evapotranspiration values is an important tool in the decision-making related to the agricultural activities (PrelaPantano et al., 2009).
In irrigation projects, the criterion for choosing the probability level should be based on an economic analysis, considering the losses associated with the reduction of quantity and quality of production, due to the water deficit and the increase of costs of the system to satisfy higher levels of probability.

The value of Eto with $75 \%$ probability has been recommended for the design of irrigation projects (Back, 2007).

Commonly, probability distribution models are used to adjust the evapotranspiration data (Pereira and Frizzone, 1994). The use of these probability density functions is directly linked to the nature of the data. Once the data representativeness is taken into account, the estimates of the parameters for a given region can be established, without prejudice to the precision in the estimation of probability (Catalunha et al., 2002).

Several works has been performed for probability distribution using function of theoretical distribution related to climatic variables, such as evapotranspiration. Assis et al. (2014) verified that the reference evapotranspiration data from Mossoró-RN can be adjusted to the normal probability distribution. On the other hand, Silva et al. (2015) observed 
that the normal and gamma distributions were able to represent the Petrolina-PE reference evapotranspiration data, for the cumulative periods of 10,15 and 30 days.

Silva et al. (2014) verified the presence of theoretical distribution of probability by means of the chi-square and the Kolmogorov-Smirnov test (at $5 \%$ of significance) in Crateús, Quixeramobim and Tauá in the state of Ceará. Then, normal, log-normal and range distributions were adjusted to monthly reference evapotranspiration (Eto) data in all months of the year. Vellame, Queiroz and Oliveira (2012), verified that the Beta distribution presented a better fit to the potential evapotranspiration data in relation to the normal distribution.

The objective of this study was to elaborate probability of tables for decennial reference evapotranspiration (Etr) (in $\mathrm{mm}$ day), in accumulation periods of 10 days, using the theoretical distribution of Normal probability density, as well as to determine the return periods at different levels of probability.

\section{Results and Discussion}

Adjustment of the statistical model was carried out, using estimation of two parameters of normal probability density and distribution equation (Table 1). The behavior of the reference evapotranspiration in each studied decennial period, exhibited a high approval of non-parametric tests (KS), Wilcoxon (W2), Anderson-Darling (AD) and Chi-square (10\%) probability, as well as application of the maximum likelihood logarithm criterion (Tables 2, 3, 4, 5, 6, 7, 8, 9, 10, 11,12 and 13). The normal probability distribution showed a good fit or adhesion to represent the decennial reference evapotranspiration behavior. Similar results were reported by Costa Neto (2002), Abumanssur (2006), Blain and Brunini (2007) and Arraes et al. (2009).

It is worth noting that this model of the normal distribution of probabilities presents good parsimony due to the simplicity of its equation, low number of parameters to be estimated, easy estimation and wide use in statistical inference studies, with good percentage of adherence to the series studied.

In the Kolmogorov-Smirnov test we observed that, regardless of the capacity of the distribution to estimate the frequencies observed and the number of classes, the critical value depends only on the number of observations. There is no variation for distribution, depending only on the series under the test (Catalunha et al., 2002, Martins et al., 2010; Martins et al., 2011).

Considering the chi-square test, we verified that the degree of freedom depends on the distribution parameters such as function of two or three, and the number of classes that is a characteristic of the data.

According to Catalunha et al. (2002), this number reduces when the distribution underestimates the final classes, due to the grouping of some classes and the degree of freedom becomes smaller, reducing the tabulated critical value. This shows that the critical value for the chi-square depends on the ability of the distribution to estimate the frequencies observed, which does not occur in the Kolmogorov-Smirnov test. This happens even though the Kolmogorov-Smirnov test is widely used for distribution adherence analysis in climatic and hydrological studies.
For example, for a cumulative Eto period of the first 10 days in January, the probability of occurrence is $95 \%$, with a return period of 20 years, with the Eto value corresponding to $7.58 \mathrm{~mm} \mathrm{day}^{-1}$. Therefore, there is a $95 \%$ probability that the Eto value for a period of 10 days does not exceed 7.58 $\mathrm{mm} \mathrm{dia}{ }^{-1}$, and for the same period, one of every twenty years, the value of Eto will be equal to or greater than 7.58 $\mathrm{mm} \mathrm{dia}^{-1}$.

The advantage of the estimated values through the normal distribution is to guide the researcher to design irrigation systems, and performing statistical inference through parameter estimation. It also can help to probabilistic forecasts and comparison of accumulated Eto and to return periods by constructing confidence intervals. Furthermore, it assists to high estimations for a fixed estimation or sampling error, applying hypothesis tests, regression models for predictions, measuring variability or heterogeneity, estimating the degree of asymmetry and kurtosis of responses. It also can assess the risks inherent in this important random variable for agriculture in this region.

It is verified that in the first ten-day of January showed higher value of probability or risk, lowering the estimated value of the reference evapotranspiration in this period (Table 14). On the other hand, the data show that there is at least a $75 \%$ probability for the reference evapotranspiration value to assume $6.90 \mathrm{~mm}$ day $^{-1}$. In the last December, we observed that there is a maximum probability of $75 \%$. So that, the reference evapotranspiration value does not exceed $6.89 \mathrm{~mm} \mathrm{dia}^{-1}$. It shows that the use of the model can safely aid the management of agricultural activities, such as design of irrigation systems, crop water requirements, cost estimation, material acquisition, crop forecasting, production estimation, present and future needs (Meyer, 2012; Lanna, 2001; Costa Neto, 2002; Bussab and Morettin, 2013; Dallacort, 2011).

The Eto values multiplied by the respective crop coefficients can be used as a parameter for the design of irrigation systems in the region of Mossoró, RN, Brazil. For example, during the maize flowering, the period for maximum water requirement is about 20 days and crop coefficient is 1.05 (Doorenbos and Kassam, 1994).

Under these conditions and adopting $75 \%$ as probability level (return period of 4 years), the recommended evapotranspiration as a parameter for the design of irrigation systems for the dourados region was $6.18 \mathrm{~mm}$ day 1 (5.89 x 1.05). The Eto recommended as a parameter for design of irrigation systems was $8.20 \mathrm{~mm} \mathrm{dia}^{-1}$ (7.81 x 1.05) in October in Mossoró, RN. This value was calculated for a period of maximum water requirement, with a duration of 10 days, using the last decade data for the same crop, adopting a level of probability or risk of $75 \%$ (return period of 4 years)(Table 14).

Therefore, in this case there is a $75 \%$ probability that the value of Eto for a period of the last ten days in October does not exceed $8.20 \mathrm{~mm} \mathrm{day}^{-1}$. For the same period, in only one of every four years the value of Eto will be at least or equal to $8.20 \mathrm{~mm}$ day $^{-1}$. It can be seen that the estimated reference evapotranspiration values with $75 \%$ probability through the Normal distribution vary according to the month of the year. Marques Jr., Saad and Moura (1995) adopted the concept of dependent precipitation, quoting Doorenbos and Kassam (1994), to apply the 
Table 1. Normal distribution of probability applied to the reference evapotranspiration variable (Eto) in the months of January, February, March, April, May, June, July, August, September, October, November and December, between 1970 and 2007 in Mossoró, Brazil.

\begin{tabular}{|c|c|c|c|}
\hline \multirow{2}{*}{ Distribution } & \multirow{2}{*}{ Month } & \multicolumn{2}{|c|}{ Parameter } \\
\hline & & $\mu$ & $\sigma^{2}$ \\
\hline & $\mathrm{J} 1$ & 6.43184 & 0.69540 \\
\hline \multirow[t]{3}{*}{ Normal } & $\mathrm{J} 2$ & 6.11868 & 1.17957 \\
\hline & $\mathrm{J3}$ & 5.88579 & 1.39311 \\
\hline & F1 & 5.81395 & 1.17809 \\
\hline \multirow[t]{3}{*}{ Normal } & $\mathrm{F} 2$ & 5.44711 & 1.07889 \\
\hline & $\mathrm{F} 3$ & 5.52369 & 1.84497 \\
\hline & M1 & 5.21763 & 1.36140 \\
\hline \multirow[t]{3}{*}{ Normal } & M2 & 4.80579 & 0.93367 \\
\hline & M3 & 4.55921 & 0.85051 \\
\hline & A1 & 4.55290 & 0.82398 \\
\hline \multirow[t]{3}{*}{ Normal } & $\mathrm{A} 2$ & 4.58395 & 0.91022 \\
\hline & $\mathrm{A} 3$ & 4.49500 & 0.90294 \\
\hline & M1 & 4.53263 & 0.81359 \\
\hline \multirow[t]{3}{*}{ Normal } & $\mathrm{M} 2$ & 4.62474 & 0.67785 \\
\hline & M3 & 4.74000 & 0.90980 \\
\hline & $\mathrm{J} 1$ & 4.54447 & 0.61267 \\
\hline \multirow[t]{3}{*}{ Normal } & $\mathrm{J} 2$ & 4.64842 & 0.53894 \\
\hline & $\mathrm{J} 3$ & 4.71211 & 0.73717 \\
\hline & $\mathrm{J} 1$ & 4.91368 & 0.88808 \\
\hline \multirow[t]{3}{*}{ Normal } & $\mathrm{J} 2$ & 5.52737 & 1.00307 \\
\hline & $\mathrm{J} 3$ & 5.52737 & 1.00307 \\
\hline & $\mathrm{A} 1$ & 6.16868 & 0.99611 \\
\hline \multirow[t]{3}{*}{ Normal } & $\mathrm{A} 2$ & 6.50868 & 0.43385 \\
\hline & $\mathrm{A} 3$ & 6.84842 & 0.47991 \\
\hline & S1 & 7.00474 & 0.53104 \\
\hline \multirow[t]{3}{*}{ Normal } & S2 & 7.25289 & 0.76853 \\
\hline & S3 & 7.38869 & 0.82844 \\
\hline & 01 & 7,45711 & 0.70420 \\
\hline \multirow[t]{3}{*}{ Normal } & $\mathrm{O} 2$ & 7.48632 & 0.70956 \\
\hline & $\mathrm{O} 3$ & 7.40553 & 0.60058 \\
\hline & N1 & 7.20132 & 0.43836 \\
\hline \multirow[t]{3}{*}{ Normal } & N2 & 7.11763 & 0.55929 \\
\hline & N3 & 6.96263 & 0.74787 \\
\hline & D1 & 6.56342 & 1.38086 \\
\hline \multirow[t]{2}{*}{ Normal } & D2 & 6.37605 & 1.45210 \\
\hline & D3 & 6.02921 & 1.27151 \\
\hline
\end{tabular}

Table 2. Results of the adjustment criteria for the decennial variable evapotranspiration reference, following the Normal distributions for the month of January, in the period from 1970 to 2007 in the Northeast Brazil.

\begin{tabular}{|c|c|c|c|c|c|c|}
\hline \multirow{2}{*}{ Distribution } & \multirow{2}{*}{ Dec } & \multicolumn{5}{|c|}{ Adjustment quality criteria } \\
\hline & & KS & $\mathrm{V}$ & $W^{2}$ & $A D$ & $\chi^{2}$ \\
\hline \multirow{3}{*}{ Normal } & J1 & $\mathrm{N}$ & $\mathrm{N}$ & $\mathrm{N}$ & $\mathrm{N}$ & $\mathrm{N}$ \\
\hline & $\mathrm{J} 2$ & $\mathrm{~N}$ & $\mathrm{~N}$ & $\mathrm{~N}$ & $\mathrm{~N}$ & $\mathrm{~N}$ \\
\hline & $\mathrm{J} 3$ & $\mathrm{~N}$ & $\mathrm{~N}$ & $\mathrm{~N}$ & $\mathrm{~N}$ & $\mathrm{~N}$ \\
\hline
\end{tabular}

Source: Historical series of reference evapotranspiration in Mossoró, Brazil.

Table 3. Results of the adjustment criteria for the decennial variable evapotranspiration reference, following the normal distributions, for the month of February, in the period from 1970 to 2007 in the Northeast Brazil.

\begin{tabular}{lcccccc}
\hline \multirow{2}{*}{ Distribution } & \multirow{2}{*}{ Dec } & \multicolumn{5}{c}{ Adjustment quality criteria } \\
\cline { 3 - 7 } Normal & & KS & V & W $^{2}$ & AD & $\chi^{2}$ \\
\hline & F1 & N & N & N & N & N \\
& F3 & N & N & N & N & N \\
\hline
\end{tabular}


Table 4. Results of the adjustment criteria for the decennial variable evapotranspiration reference, following the normal distributions, for the month of march, in the period from 1970 to 2007 in Mossoró, Brazil.

\begin{tabular}{|c|c|c|c|c|c|c|}
\hline \multirow{2}{*}{ Distribution } & \multirow{2}{*}{ Dec } & \multicolumn{5}{|c|}{ Adjustment quality criteria } \\
\hline & & $\mathrm{KS}$ & $\mathrm{V}$ & $W^{2}$ & $A D$ & $\chi^{2}$ \\
\hline \multirow{3}{*}{ Normal } & M1 & $\mathrm{N}$ & $\mathrm{N}$ & $N$ & $\mathrm{~N}$ & $\mathrm{~N}$ \\
\hline & M2 & $\mathrm{N}$ & $\mathrm{N}$ & $\mathrm{N}$ & $\mathrm{N}$ & $\mathrm{N}$ \\
\hline & M3 & $\mathrm{N}$ & $\mathrm{N}$ & $\mathrm{N}$ & $\mathrm{N}$ & $\mathrm{N}$ \\
\hline
\end{tabular}

Source: Historical series of reference evapotranspiration in Mossoró, Brazil

Table 5. Results of the adjustment criteria for the decennial variable evapotranspiration reference, following the normal distributions, for the month of April, in the period from 1970 to 2007 in Mossoró, Brazil.

\begin{tabular}{lllllll}
\hline \multirow{2}{*}{ Distribution } & \multirow{2}{*}{ Dec } & \multicolumn{5}{c}{ Adjustment quality criteria } \\
\cline { 2 - 7 } Normal & $\mathrm{A} 1$ & $\mathrm{NS}$ & $\mathrm{N}$ & $\mathrm{W}$ & $\mathrm{AD}$ & $\chi^{2}$ \\
\hline \multirow{3}{*}{ A2 } & $\mathrm{N}$ & $\mathrm{N}$ & $\mathrm{N}$ & $\mathrm{N}$ & $\mathrm{N}$ \\
& $\mathrm{N}$ & $\mathrm{N}$ & $\mathrm{N}$ & $\mathrm{N}$ & $\mathrm{N}$ \\
\hline
\end{tabular}

Source: Historical series of reference evapotranspiration in Mossoró, Brazil

Table 6. Results of the adjustment criteria for the decennial variable evapotranspiration reference, following the Normal distributions, for the month of may, in the period from 1970 to 2007 in Mossoró, Brazil.

\begin{tabular}{|c|c|c|c|c|c|c|}
\hline \multirow{2}{*}{ Distribution } & \multirow{2}{*}{ Dec } & \multicolumn{5}{|c|}{ Adjustment quality criteria } \\
\hline & & KS & $\mathrm{V}$ & $W^{2}$ & $A D$ & $\chi^{2}$ \\
\hline \multirow{3}{*}{ Normal } & M1 & $\mathrm{N}$ & $\mathrm{N}$ & $\mathrm{N}$ & $\mathrm{N}$ & $\mathrm{N}$ \\
\hline & $\mathrm{M} 2$ & $\mathrm{~N}$ & - & $\mathrm{N}$ & $\mathrm{N}$ & $\mathrm{N}$ \\
\hline & M3 & $\mathrm{N}$ & $\mathrm{N}$ & $\mathrm{N}$ & $\mathrm{N}$ & $\mathrm{N}$ \\
\hline
\end{tabular}

Source: Historical series of reference evapotranspiration in Mossoró, Brazil

Table 7. Results of the adjustment criteria for the decennial variable evapotranspiration reference, following the normal distributions, for the month of june, in the period from 1970 to 2007 in Mossoró, Brazil.

\begin{tabular}{lcccccc}
\hline \multirow{2}{*}{ Distribution } & \multirow{2}{*}{ Dec } & \multicolumn{5}{c}{ Adjustment quality criteria } \\
\cline { 2 - 7 } & & $\mathrm{KS}$ & $\mathrm{V}$ & $\mathrm{W}^{2}$ & $\mathrm{AD}$ & $\chi^{2}$ \\
\hline \multirow{3}{*}{ Normal } & $\mathrm{J} 1$ & $\mathrm{~N}$ & - & $\mathrm{N}$ & $\mathrm{N}$ & $\mathrm{N}$ \\
& $\mathrm{J}$ & $\mathrm{N}$ & - & $\mathrm{N}$ & $\mathrm{N}$ & $\mathrm{N}$ \\
& $\mathrm{J}$ & $\mathrm{N}$ & - & $\mathrm{N}$ & $\mathrm{N}$ & $\mathrm{N}$ \\
\hline
\end{tabular}

Source: Historical series of reference evapotranspiration in Mossoró, Brazil

Table 8. Results of the adjustment criteria for the decennial variable evapotranspiration reference, following the Normal distributions, for the month of July, in the period from 1970 to 2007 in Mossoró, Brazil.

\begin{tabular}{lcccccc}
\hline \multirow{2}{*}{ Distribution } & \multirow{2}{*}{ Dec } & \multicolumn{5}{c}{ Adjustment quality criteria } \\
\cline { 3 - 7 } & $\mathrm{J} 1$ & $\mathrm{KS}$ & $\mathrm{V}$ & $\mathrm{W}$ & $\mathrm{AD}$ & $\chi^{2}$ \\
\multirow{3}{*}{ Normal } & $\mathrm{N}$ & $\mathrm{N}$ & $\mathrm{N}$ & $\mathrm{N}$ & $\mathrm{N}$ \\
& $\mathrm{J} 2$ & $\mathrm{~N}$ & - & $\mathrm{N}$ & $\mathrm{N}$ & $\mathrm{N}$ \\
Source: Historical series of reference evapotranspiration in Mossoró, Brazil & $\mathrm{N}$ & - & $\mathrm{N}$ & $\mathrm{N}$ & $\mathrm{N}$ \\
\hline
\end{tabular}

Table 9. Results of the adjustment criteria for the decennial variable evapotranspiration reference, following the Normal distributions, for the month of august, in the period from 1970 to 2007 in Mossoró, Brazil.

\begin{tabular}{lcccccc}
\hline \multirow{2}{*}{ Distribution } & \multirow{2}{*}{ Dec } & \multicolumn{5}{c}{ Adjustment quality criteria } \\
\cline { 3 - 7 } & & $\mathrm{KS}$ & $\mathrm{V}$ & $\mathrm{W}^{2}$ & $\mathrm{AD}$ & $\chi^{2}$ \\
\multirow{3}{*}{ Normal } & $\mathrm{A} 1$ & $\mathrm{~N}$ & $\mathrm{~N}$ & $\mathrm{~N}$ & $\mathrm{~N}$ & $\mathrm{~N}$ \\
& $\mathrm{~A} 2$ & $\mathrm{~N}$ & $\mathrm{~N}$ & $\mathrm{~N}$ & $\mathrm{~N}$ & $\mathrm{~N}$ \\
\hline
\end{tabular}

Source: Historical series of reference evapotranspiration in Mossoró, Brazil

Table 10. Results of the adjustment criteria for the decennial variable evapotranspiration reference, following the Normal distributions, for the month of september, in the period from 1970 to 2007 in Mossoró, Brazil.

\begin{tabular}{lcccccc}
\hline \multirow{2}{*}{ Distribution } & \multirow{2}{*}{ Dec } & \multicolumn{5}{c}{ Adjustment quality criteria } \\
\cline { 3 - 7 } & & $\mathrm{KS}$ & $\mathrm{V}$ & $\mathrm{W}^{2}$ & $\mathrm{AD}$ & $\chi^{2}$ \\
\hline \multirow{3}{*}{ Normal } & $\mathrm{S} 1$ & $\mathrm{~N}$ & $\mathrm{~N}$ & $\mathrm{~N}$ & $\mathrm{~N}$ & $\mathrm{~N}$ \\
& $\mathrm{~S} 2$ & $\mathrm{~N}$ & - & $\mathrm{N}$ & $\mathrm{N}$ & $\mathrm{N}$ \\
\hline
\end{tabular}


Table 11. Results of the adjustment criteria for the decennial variable evapotranspiration reference, following the Normal distributions, for the month of October, in the period from 1970 to 2007 in Mossoró, Brazil.

\begin{tabular}{|c|c|c|c|c|c|c|}
\hline \multirow{2}{*}{ Distribution } & \multirow{2}{*}{ Dec } & \multicolumn{5}{|c|}{ Adjustment quality criteria } \\
\hline & & $\mathrm{KS}$ & $\mathrm{V}$ & $W^{2}$ & $A D$ & $\chi^{2}$ \\
\hline \multirow{3}{*}{ Normal } & 01 & $\mathrm{~N}$ & $\mathrm{~N}$ & $\mathrm{~N}$ & $\mathrm{~N}$ & $\mathrm{~N}$ \\
\hline & $\mathrm{O} 2$ & $\mathrm{~N}$ & $\mathrm{~N}$ & $\mathrm{~N}$ & $\mathrm{~N}$ & $\mathrm{~N}$ \\
\hline & 03 & $\mathrm{~N}$ & $\mathrm{~N}$ & $\mathrm{~N}$ & $\mathrm{~N}$ & $\mathrm{~N}$ \\
\hline
\end{tabular}

Source: Historical series of reference evapotranspiration in Mossoró, Brazil.

Table 12. Results of the adjustment criteria for the decennial variable evapotranspiration reference, following the Normal distributions, for the month of November, in the period from 1970 to 2007 in Mossoró, Brazil.

\begin{tabular}{lcccccc}
\hline \multirow{2}{*}{ Distribution } & \multirow{2}{*}{ Dec } & \multicolumn{5}{c}{ Adjustment quality criteria } \\
\cline { 3 - 7 } & & $\mathrm{KS}$ & $\mathrm{V}$ & $\mathrm{W}^{2}$ & $\mathrm{AD}$ & $\chi^{2}$ \\
\hline \multirow{3}{*}{ Normal } & $\mathrm{N} 1$ & $\mathrm{~N}$ & $\mathrm{~N}$ & $\mathrm{~N}$ & $\mathrm{~N}$ & $\mathrm{~N}$ \\
& $\mathrm{~N} 2$ & $\mathrm{~N}$ & $\mathrm{~N}$ & $\mathrm{~N}$ & $\mathrm{~N}$ & $\mathrm{~N}$ \\
& $\mathrm{~N} 3$ & $\mathrm{~N}$ & $\mathrm{~N}$ & $\mathrm{~N}$ & $\mathrm{~N}$ & $\mathrm{~N}$ \\
\hline
\end{tabular}

Source: Historical series of reference evapotranspiration in Mossoró, Brazil.

Table 13. Results of the adjustment criteria for the decennial variable evapotranspiration reference, following the Normal distributions, for the month of december, in the period from 1970 to 2007 in Mossoró.

\begin{tabular}{|c|c|c|c|c|c|c|}
\hline \multirow{2}{*}{ Distribution } & \multirow{2}{*}{ Dec } & \multicolumn{5}{|c|}{ Adjustment quality criteria } \\
\hline & & KS & $\mathrm{V}$ & $W^{2}$ & $A D$ & $\chi^{2}$ \\
\hline \multirow{3}{*}{ Normal } & D1 & $\mathrm{N}$ & - & $\mathrm{N}$ & $\mathrm{N}$ & $\mathrm{N}$ \\
\hline & D2 & $\mathrm{N}$ & - & $\mathrm{N}$ & $\mathrm{N}$ & $\mathrm{N}$ \\
\hline & D3 & $\mathrm{N}$ & $\mathrm{N}$ & $\mathrm{N}$ & $\mathrm{N}$ & $\mathrm{N}$ \\
\hline
\end{tabular}

Source: Historical series of reference evapotranspiration in Mossoró, Brazil.

Table 14. Different levels of cumulative probability of occurrence for decennial average reference evapotranspiration, the quantile values of the probability distribution and return period according to the Normal or Gaussian distribution for Mossoró, RN, Brazil.

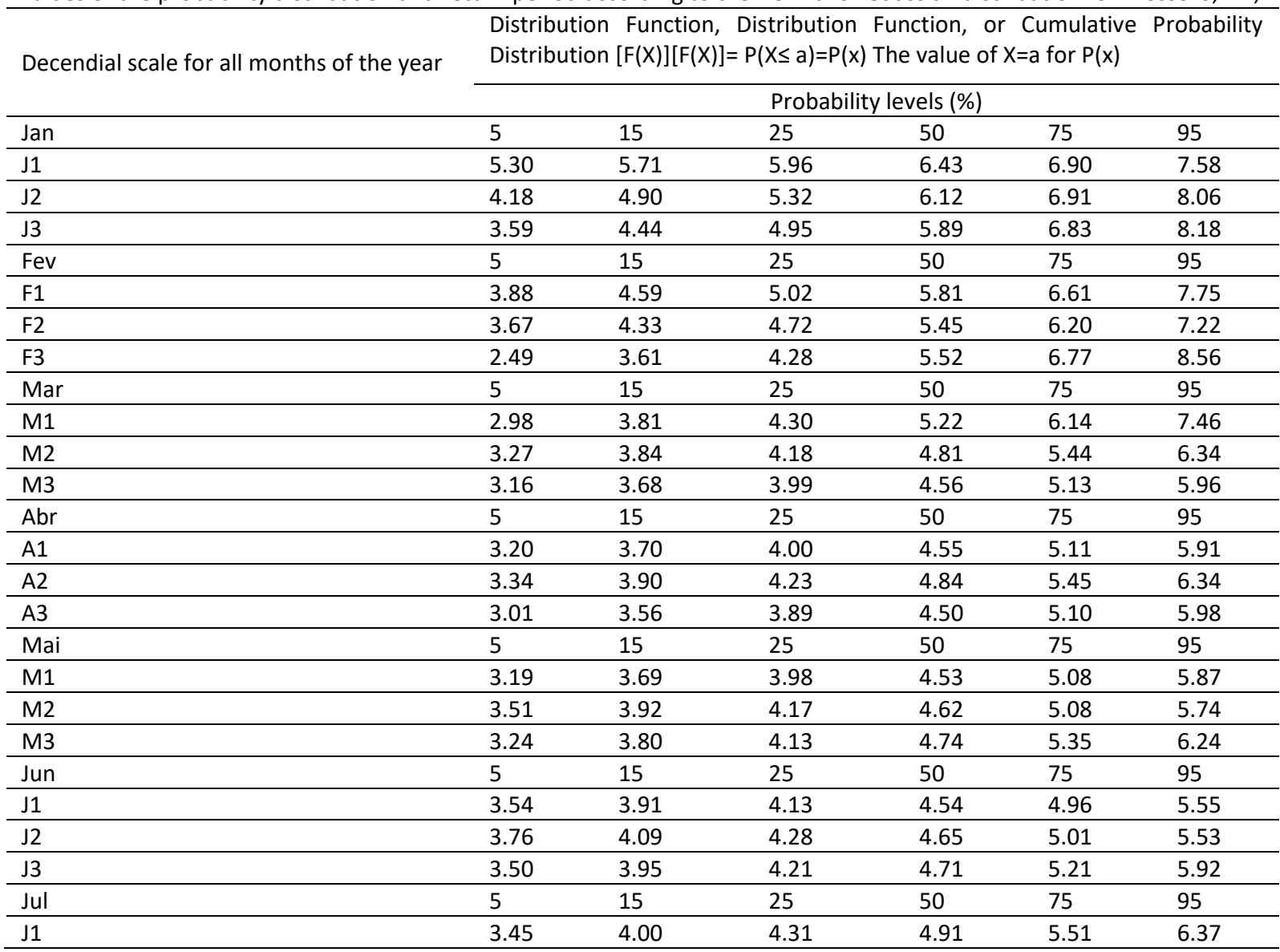




\begin{tabular}{lllllll}
\hline J2 & 3.88 & 4.49 & 4.85 & 5.53 & 6.20 & 7.18 \\
\hline J3 & 3.88 & 4.49 & 4.85 & 5.53 & 6.20 & 7.18 \\
\hline Ago 1 & 5 & 15 & 25 & 50 & 75 & 95 \\
\hline A2 & 4.53 & 5.14 & 5.50 & 6.17 & 6.84 & 7.81 \\
\hline A3 & 5.80 & 6.06 & 6.22 & 6.22 & 6.51 & 7.22 \\
\hline Set & 6.06 & 6.35 & 6.52 & 6.85 & 7.17 & 7.64 \\
\hline S1 & 5 & 15 & 25 & 50 & 75 & 95 \\
\hline S2 & 6.13 & 6.45 & 6.65 & 7.00 & 7.36 & 7.88 \\
\hline S3 & 5.99 & 6.46 & 6.73 & 7.25 & 7.77 & 8.52 \\
\hline Out & 6.03 & 6.53 & 6.83 & 7.39 & 7.95 & 8.75 \\
\hline O1 & 5 & 15 & 25 & 50 & 75 & 95 \\
\hline O2 & 6.30 & 6.73 & 6.98 & 7.46 & 7.93 & 8.62 \\
\hline O3 & 6.32 & 6.75 & 7.01 & 7.49 & 7.96 & 8.65 \\
\hline Nov & 6.42 & 6.78 & 7.00 & 7.41 & 7.81 & 8.39 \\
\hline N1 & 5 & 15 & 25 & 50 & 75 & 95 \\
\hline N2 & 6.48 & 6.75 & 6.91 & 7.20 & 7.50 & 7.92 \\
\hline N3 & 6.20 & 6.54 & 6.74 & 7.12 & 7.49 & 8.04 \\
\hline Dez & 5.73 & 6.19 & 6.46 & 6.96 & 7.47 & 8.19 \\
\hline D1 & 5 & 15 & 25 & 50 & 75 & 95 \\
\hline D2 & 4.29 & 5.13 & 5.63 & 6.56 & 7.49 & 8.83 \\
\hline D3 & 3.99 & 4.87 & 5.40 & 6.38 & 7.36 & 8.76 \\
\hline Return period (in years) & 3.94 & 4.71 & 5.17 & 6.03 & 6.89 & 8.12 \\
\hline Nea
\end{tabular}

Return period or recurrence time (T): Average time measured in years in which a given atmospheric, meteorological or hydrological event must be matched or exceeded for at least at least once, at least once or once.

determination of the so-called design evapotranspiration obtained at a $75 \%$ probability level. Table 14 , represents the probability levels and limits of occurrence of values equal to or lower than those established. Therefore, for a cumulative 10-day evapotranspiration period in January, there is a $75 \%$ probability that the evapotranspiration value will not exceed $6.90 \mathrm{~mm}$. day ${ }^{-1}$. For example, for the period of only one in four years, the value of evapotranspiration will be equal to or greater than $6.90 \mathrm{~mm}$. day ${ }^{-1}$. Similar results were obtained by other authors such as Abumanssur (2006) and Arraes et al. (2009).

According to the results shown in Table 14, the return period is increased as a function of the evapotranspiration values, as well as that of the potential evapotranspiration estimated by the Gaussian model, when the probability of occurrence is increased. It remains very similar between the decennial periods in all twelve months of evaluation.

\section{Materials and methods}

\section{Place of study}

The data were obtained from a series of 38 years (1970 to 2007), from the records of the of the Federal Rural Semi-Arid University (UFERSA), in Mossoró, RN, with geographic coordinates of 5011 'S and 37o20' W and $18 \mathrm{~m}$ altitude, with an average annual temperature around $27.5^{\circ} \mathrm{C}$ and relative humidity of $68.9 \%$ (Carmo Filho et al., 1991). According to Kottek et al. (2006) and the classification of Köppen, the local climate is BSwh, dry and very hot. The dry season normally extends from June to January, and a rainy season from February to May.

The values of Eto (reference evapotranspiration) were accumulated in consecutive periods of 10 days, and then analyzed using program R, Version 3.1.1 (2018), to verify the adjustment of the accumulated Eto to the probability distribution of Normal model, with confidence levels of $1 \%$ to $95 \%$, where adjustments are performed through nonparametric tests Kolmogorv-Smirnov (KS), Wilcoxon (W2), Anderson-Darling (AD) and Chi-square \% probability (Catalunha et al., 2002). The Maximum Likelihood Logarithm (V) was applied to verify the occurrence of a higher frequency of acceptance of the null hypothesis (Assis et al., 2018). The data of the studied phenomena is represented by the normal probability model.

According to Bussab and Morettin (2013), the normal or Gaussian probability density distribution is one of the most important models for continuous random variables. The random variable $X$, which takes all real values $(-\infty<X<+\infty)$, has a normal distribution if its probability density function is as follows:

$$
f(X)=\frac{1}{\sqrt{2 \pi \sigma^{2}}} \cdot \exp \left[-\frac{1}{2}\left(\frac{X-\mu}{\sigma}\right)^{2}\right] \text {, for }-\infty<\mathrm{X}<+\infty
$$

refers to the mean of the random variable and the standard deviation. The probability that a random variable $X$ assumes values between two real limits $a$ and $b x$ when it has $a$ normal distribution with mean $\mu$ and variance $\sigma^{2}[N(\mu, \sigma 2)]$, is calculated by

$$
\mathrm{P}(\mathrm{a} \leq \mathrm{X} \leq \mathrm{b})=\frac{1}{\sigma \sqrt{2 \pi}} \int_{\mathrm{a}}^{\mathrm{b}} \mathrm{e}^{-\frac{(\mathrm{x}-\mu)^{2}}{2 \sigma^{2}}} \mathrm{dx} \text { (Meyer, 2012). }
$$

This equation cannot be solved analytically only with the use of numerical integration. For this reason, the $Z=(x-\mu) / \sigma$ transformation is used, and this $\mathrm{Z}$ variable has standard normal distribution with zero mean and variance one [ $\mathrm{N}$ (0.1)]. The variable $Z$ is reduced and the cumulative distribution equation can be rewritten as follows:

$F(Z)=\frac{1}{\sqrt{2 \pi}} \int_{-\infty}^{Z} \exp \left[-\frac{1}{2}(Z)^{2}\right]$, for $-\infty<Z<+\infty$ 
The chi-square test $\left(\chi^{2}\right)$ is a statistical application that aims to determine if a set of observed data is compatible with the expected values. For this, a null hypothesis is tested assuming that the distribution is the one specified and used in the study (normal, log-normal and range), with their parameters estimated based on the sample data. The hypothesis is tested by comparing the frequencies observed and the theoretical or expected frequencies, in each class of frequency of the data, through the test statistic given by

$\chi^{2}=\sum_{i=1}^{K}\left[\frac{\left(F_{O_{i}}-F_{e_{i}}\right)^{2}}{F_{e_{i}}}\right]$

Where; $\mathrm{K}$ is the number of classes. The observed frequency and the expected frequency under the $\mathrm{HO}$ hypothesis according to the distribution was tested (Campos, 1983). The critical or tabulated values for some significance levels $\alpha$ are described by their own tables.

It should be noted that this statistic is associated with a degree of freedom $(v)$ defined by the subtraction of the number of frequency distribution classes of the number of estimated parameters and the minimum expected frequency, ie, $v=K-P-1$ where; $\mathrm{K}$ is the number of classes and $P$ the number of estimated parameters.

The Kolmogorov-Smirnov (KS) adherence test is a nonparametric test based on the difference between cumulative, empirical and theoretical probabilities functions. This fit test is used to evaluate whether the null hypothesis that the data from a population is represented by the assumed probability distribution, as well as the chi-square test.

It was designed as a function of the chi-square test failures, which produces precise results only for discrete distributions. The KS test has the advantage of not making assumptions, removing the arbitrary character and loss of information that accompanies the class-grouping process, estimated by the probability distributions (Campos, 1983).

Considering the above, the mathematical model that represents the KS test can be expressed as shown in the equation below (Tiberius and Borre, 1999):

$D=\sup _{-\infty<x<\infty}\left|F_{N(X)}-F_{o(X)}\right|$

From the calculated value $D$ of the Kolmogorov-Smirnov test, and from the table value $\mathrm{Dk}$, which is obtained as a function of the number of sample elements and the level of significance, the null hypothesis is verified, accepted or rejected, when FN $(x)$ and FO $(x)$ are the same or not (Tiberius and Borre, 1999).

The estimated value of decennial evapotranspiration was obtained using the Penman-Monteith method, used by Pereira et al. (2002), adapted to the data from the Mossoró region, Brazil.

The combined Penman-Monteith method was used for calculation of Eto of the hypothetical culture, when incorporated into the surface resistance of $70 \mathrm{sm}^{-1}$ with aerodynamic resistance fixed to grass in $0.12 \mathrm{~m}$ of uniform height for the purposes of standardization (Sediyama et al., 1996), by the equation below, using program R. Version 3.1.1 (2018):

$$
E t o=\frac{0.408 \cdot S\left(R_{n}-G\right)+\frac{\gamma \cdot 900 \cdot V_{2} \cdot\left(e_{3}-e\right)}{t+273}}{S+\gamma\left(1+0.34 V_{2}\right)}
$$

Where; $R n$ is the total daily net solar radiation $\left(\mathrm{MJ} \mathrm{m}^{-2} \mathrm{~d}^{-1}\right), \mathrm{G}$ is the soil surface heat flux $\left(\mathrm{MJ} \mathrm{m} \mathrm{m}^{-2} \mathrm{~d}^{-1}\right),=0.063 \mathrm{KPa},{ }^{\circ} \mathrm{C}^{-1}$ is the constant $\left(\mathrm{m} \mathrm{s}^{-1}\right), \mathrm{s}$ is the saturation pressure; $(\mathrm{kPa})$ is the current pressure of the vapor $d(\mathrm{kPa})$ and $\mathrm{S}$ is the slope of the vapor pressure curve at the air temperature, in $\mathrm{Kpa}{ }^{\circ} \mathrm{C}$, calculated by

$\mathrm{S}=\frac{4098 \cdot \mathrm{e}_{\mathrm{s}}}{(\mathrm{t}+273)^{2}}$

Bertoni and Tucci (2007) report that the period of return or recurrence $(\mathrm{Tr})$ can be interpreted as the average number of years, during which potential evapotranspiration is expected to be matched or exceeded. The inverse of the probability of occurrence is termed in hydrology and return period meteorology or recurrence interval. Thus, if a given hydrologic quantity has the probability of being equal or exceeded equal to $5 \%(p=0.05)$ its return period will be: $T=$ $I / p=1 / 0.05=20$ years. The payback period is expressed in years. So, if a flood is matched or exceeded on average every 20 years it will have a return period $\mathrm{T}=20$ years. On other words, this has a $5 \%$ probability of being matched or exceeded in any year. If a hydraulic work is designed to last only 1 year (a dam, for example) the risk that it is exceeded by a flood is equal to the probability of this flood. Works that have to last for several years expose themselves to a risk equal to the probability of occurrence of project flow (Guimarães, 2011). The payback period can be obtained by the following equation:

$\operatorname{Tr}=\frac{1}{\mathrm{P}}$,

Where $\mathrm{P}$; is the probability of the study variable to be matched or exceeded, where values are $5 \%, 15 \%, 25 \%, 50 \%$, $75 \%$ and $95 \%$.

In order to analyze the minimum values of some hydrological variable, or any random variable, we must change the interpretation, in the sense of smaller values than the one analyzed. Therefore, we must calculate the cumulative probability of the variable. The payback period in this case is the inverse of the probability of non-exceedance.

\section{Conclusions}

After the application of the adhesion tests, we verified that the theoretical density distribution of Normal or Gaussian probability presented adherence to the historical series of 38 years of the reference evapotranspiration for the consecutive periods of 10 days, allowing the model for estimates of the amount of reference evapotranspiration at different levels of probability. The Gaussian model was used to simulate this climatic variable and estimation of probability of risk or probable evapotranspiration value.

\section{Acknowledgements}

Special thank the Jitirana (Merremia aegyptia L.) Research Group committed to the study of spontaneous species of the Caatinga Biome as fertilizer source and the Department of Agronomic and Forestry Sciences the Federal Rural SemiArid University (UFERSA), for the support to conduct the 
project.

\section{References}

Abumanssur C. (2006) Estimativa da evapotranspiração mensal no Estado do Paraná. 91 p. (Dissertação de mestrado). Universidade Estadual do. Oeste do ParanáUnioeste. Cascavel, Brazil.

Arraes FDD, Lopes FB, Souza, F, and Oliveira, B (2009) Estimativa do balanço hídrico para as condições climáticas de Iguatu, Ceará, usando modelo estocástico. Revista Brasileira de Agricultura Irrigada 3: 78-87.

Assis JP, Sousa RP, Batista BDO, Linhares PCF, Cardoso EA, Paula JAA, Neves AM (2018). Probabilistic Modeling of Monthly Temperature Historical Series in Mossoró, Northeastern Brazil. Journal of Agricultural Science. 10: 534-542.

Assis JP, Sousa RP, Bezerra Neto F, and Linhares PCF (2014) Tables of probabilities of reference evapotranspiration for the region of Mossoró, RN, Brazil. Revista Verde de Agroecologia e Desenvolvimento Sustentável. 9: 58-67.

Back AJ (2007) Variação da evapotranspiração de referência calculada em diferentes intervalos de tempo. Engenharia Agrícola. 27:139-145.

Bertoni JC, and Tucci CEM (2007) Precipitação. In: Tucci CEM. Hidrologia: ciência e aplicação. 2. ed. Porto Alegre, RG: UFRGS. 943 p.

Biscaro GA (2007) Meteorologia agrícola básica. 1a. Ed., UNIGRAF: Gráfica e Editora União Ltda. Cassilândia, Mato Grosso do Sul. 86 p.

Blain GC, and Brunini R (2007) Caracterização do regime de evapotranspiração real, em escala decendial, no Estado de São Paulo. Revista Brasileira de Meteorologia. 22: 75-82.

Bussab WO, and Morettin PA (2013) Estatística Básica. São Paulo: Saraiva, 8. ed. 526 p.

Campos H (1983) Estatística experimental não-paramétrica. 4 ed. Piracicaba: ESALQ. 349 p.

Carmo Filho F, and Oliveira OF (1995) Mossoró: um município do semi-árido nordestino, caracterização climática e aspecto florístico. Mossoró: ESAM. 62 p. (Coleção Mossoroense, Série B).

Carvalho LG, Rios GFA, Miranda WL, and Castro Neto P (2011) Evapotranspiração de referência: Uma abordagem atual de diferentes métodos de estimativa. Pesquisa Agropecuária Tropical. 41: 456-465.

Catalunha MJ, Sediyama GC, Leal BG, Soares CPB and Ribeiro A (2002) Aplicação de cinco funções densidade de probabilidade a séries de precipitação pluvial no Estado de Minas Gerais. Revista Brasileira de Agrometeorologia. 10:153-162.

Costa Neto PLO (2002) Estatística. Edgar Blucher, São Paulo, $280 \mathrm{p}$.

Dallacort R, Martins JA, Inoue MH, Freitas PSL, and Coletti AJ (2011) Distribuição das chuvas no município de Tangará da Serra, médio norte do Estado de Mato Grosso, Brasil. Acta Scientiarum Agronomy. 33:193-200.

Doorenbos J, and Kassam AH (1994) Efeito da água no rendimento das culturas. Campina Grande: UFPB, 306p. (Estudos FAO: Irrigação e Drenagem, 33).

Guimarães RC (2011) Probabilidade e estatística aplicada à hidrologia. Universidade de Évora. Departamento de Engenharia Rural: Evora, Portugal, 54 P.
Kottek M, Grieser J, Rudolf B, Rubel F (2006) Mapa mundial da classificação climática de Köppen-Geiger atualizada. Meteorologische Zeitschrift. 15:259-263

Lanna AE (2001) Elementos de estatística e probabilidade. In: Tucci, C. E. M. Hidrologia: ciência e aplicação. 2. ed. Porto Alegre: ABRH; UFRGS, p. 79-176.

Leônidas PA (2011) Tendência dos elementos climáticos e da evapotranspiração da cultura do milho para a região de Viçosa. 87p. Dissertação (Mestrado), Universidade Federal de Viçosa, Brazil.

Marques Jr S, Saad JCC, and Moura MVT (1995) Modelo iterativo para estimativa da evapotranspiração de referencia provável. Scientia Agrícola. 52:221-225.

Martins JA, Dallacort R, Inoue MH, Santi A, Kolling EM, and Coletti AJ (2010) Probabilidade de precipitação para a microrregião de Tangará da Serra, estado do Mato Grosso. Pesquisa Agropecuária Tropical. 40:291-296.

Martins JA, Dallacort R, Inoue MR, Galvanin EA, Magnani EBZ, and Oliveira KC (2011) Caracterização do regime pluviométrico no arco das nascentes do rio Paraguai. Revista Brasileira de Meteorologia. 26:639-647.

Meyer PL (2012) Probabilidade: aplicações à estatística, Rio de Janeiro: Livro Técnico, $391 \mathrm{p}$.

Pereira AR, Angelocci LR, and Sentelhas PC (2002) Agrometeorologia: fundamentos e aplicações práticas. Guaíba: Agropecuária. 478p.

Pereira AS, Frizzone JA (1994) Relatório de Pesquisa. Piracicaba: Fundação de Amparo à Pesquisa do Estado de São Paulo - FAPESP. Análise de freqüência da evapotranspiração potencial para fins de dimensionamento de sistemas de irrigação: $42 \mathrm{p}$.

Prela-Pantano A, Rolin, GS, and Camargo, MBP (2009) Probability of occurrence of minimum temperature less than $5{ }^{\circ} \mathrm{c}$ at Medio Paranapanema region in the State of São Paulo, Brazil. Bragantia, Campinas, 68: 279-284.

R Version 3.1.2. (2018) Viena, Áustria: Foundation for Statistical Computing, (Software).

Sediyama T, Pereira MG, Sediyama CS, and Gomes JLL (1996) Cultura da Soja-I Parte. 3a Reimpressão. Viçosa: UFV, 96 p.

Sentelhas PC, and Angelocci LR (2007) Meteorologia agrícola-evapotranspiração. São Paulo: ESALQ/USP, 139 p.

Silva AO, Correia JS, Bassoi LH, and Teixeira AHC (2014) Evapotranspiração de referência para dimensionamento de sistemas de irrigação em Petrolina, PE. In: II Brazilian Symposium on Salinity \& II Brazilian Meeting on Irrigation Engineering, Fortaleza. Anais... II INOVAGRI International Meeting: Fortaleza, 2076-2082 p.

Silva AO, Correia JS, Bassol LH, and Teixeira AHC (2015) Evapotranspiração de referência para dimensionamento de sistemas de irrigação em Petrolina, PE Brazilian Journal of Biosystems Engineering 9:30-38.

Tilberius CCJM, Borre K (1999) Probability distribution of GPS code and phase data. Zeitschrift für Vermessungswesen. 124:264-273.

Vellame LM, Queiroz MZSS, and Oliveira AS (2012) Probabilidade de ocorrência da evapotranspiração de referência em Ouricuri-PE. In: I Inovagri International Meeting \& IV Workshop Internacional de Inovações Tecnológicas na Irrigação, Fortaleza. Anais... Fortaleza, 5p. 